\title{
Understanding collaboration among farmers and farmers' market managers in southeast Michigan (USA)
}

\author{
Crystal L. Miller ${ }^{a *}$ and Dan McCole ${ }^{b}$ \\ Michigan State University
}

Submitted October 17, 2013 / Revised December 28, 2013, and February 8, 2014 /

Accepted February 27, 2014 / Published online July 28, 2014

Citation: Miller, C. L., \& McCole, D. (2014). Understanding collaboration among farmers and farmers' market managers in southeast Michigan (USA). Journal of Agriculture, Food Systems, and Community Development, 4(4), 71-95. http://dx.doi.org/10.5304/jafscd.2014.044.003

Copyright (C) 2014 by New Leaf Associates, Inc.

\begin{abstract}
The growth in local food systems has resulted in many benefits for communities. In addition to meeting growing consumer demand, local food systems make significant positive contributions to economies, communities, and the natural environment. However, most local food systems are grassroots efforts and rely on stakeholders motivated to collaborate with each other in order to be successful. Most of the parties involved in these collaborations have very limited resources and therefore must choose carefully the collaborative initiatives in which they will invest their time and money. Too frequently collaborative initiatives are doomed to failure because the required players lack the motivation to participate at levels needed for success. Such failures can

a * Corresponding author: Crystal L. Miller, Department of Community Sustainability, Michigan State University; 480 Wilson Road, Room 131; East Lansing, Michigan 48824 USA; +1-517-803-7663; mill1879@msu.edu

b Dan McCole, Department of Community Sustainability, Michigan State University; 480 Wilson Road, Room 131; East Lansing, Micigan 48824 USA; +1-517-432-0295; mccoleda@msu.edu
\end{abstract}

damage the overall culture of collaboration within a region.

This study aims to address the lack of research into local food system collaboration by exploring the suitability of expectancy theory to understand the factors that motivate farmers and farmers' market managers to collaborate in southeast Michigan. A survey instrument was distributed to groups of farmers and farmers' market managers to measure their beliefs about collaboration's ability to generate positive outcomes as well as each group's perceived value of those outcomes. Comparisons were made between the two groups to better understand the types of collaborative initiatives that would serve the needs of both groups, as well as the initiatives that generate differing levels of motivation within each group. Results show that farmers and farmers' market managers are motivated to collaborate differently. Implications are provided for local food system players, policy-makers, and researchers.

\section{Keywords}

collaboration, local food system, farmers' markets, expectancy theory 


\section{Introduction}

Consumers are increasingly demanding foods that are produced, marketed, and distributed locally, leading to the growth of local food systems (King et al., 2010). Although these food systems compose a small portion of overall agricultural sales, directto-consumer marketing is growing rapidly and accounted for $\$ 1.2$ billion in 2007 , a $118 \%$ increase over a ten10-year period (Martinez et al., 2010). In addition to meeting consumer demand, emerging evidence suggests that local food systems are an important source of community prosperity. Local food networks may benefit communities economically in a number of ways. When farmers sell their products directly to consumers, a greater percentage of the revenues from the sale remain in the local economy (O’Hara, 2011). Moreover, as local food initiatives such as farmers' markets grow and become more stable, jobs are created in the local community (Henneberry, Whitacre, \& Agustini, 2009; Hughes, Brown, Miller, \& McConnell, 2008; Myles \& Hood, 2010; Otto \& Varner, 2005).

In addition to driving economic activity, there is also some evidence that local food systems may benefit communities in other ways, including improved health and nutrition among community members (Herman, Harrison, Afifi, \& Jenks, 2008; Racine, Vaughn \& Laditka, 2010; Schumacher, Winch \& Park, 2009). Farmers' markets, a cornerstone of local food systems, may also contribute to a stronger sense of community as they may offer more opportunities for social interaction than shopping in a grocery store (Lester, 2012; Oberholtzer \& Grow, 2003). Furthermore, the growth of local food systems may also benefit the environment. Because local foods are typically sold unprocessed directly from the producer to the consumer within the same region, less energy is consumed from activities such as transportation, food processing, storage, and preparation (O'Hara, 2011).

Although local food systems may offer benefits to communities, their success depends on a number of factors, including government regulations, expertise and technical assistance, infrastructure, and agricultural policy (Martinez et al., 2010; O'Hara, 2011). In addition to these, and in most cases at the core of these, collaborative capacity is critical to the successful development and survival of local food systems. Matopoulos, Vlachopoulou, Manthou, and Manos (2007) describe collaboration as "organizations and enterprises working together and can be viewed as a concept going beyond normal commercial relationships" (p. 178). This concept is a vital component of local food systems.

Many researchers have discussed the importance of collaboration in food systems (e.g., Alonso \& Liu, 2012; Che, Veeck \& Veeck, 2005; Hall \& Sharples, 2008; Mitchell \& van der Linden, 2010), but the significance of collaboration is demonstrated even by the vocabulary used to describe concepts important in food systems. Almost any article or report about food systems uses terms related to the concept of collaboration such as "partnership" (e.g., strategic partnerships; value chain partners), "alliance" (e.g., strategic alliances), "aggregation" (e.g., aggregated transportation services), "coordination" (e.g., coordinated supply chain logistics), "pooling" (e.g., pooling harvests), "cooperative" (e.g., food cooperatives), etc. Within local food systems, collaboration is used to improve important functions such as marketing, transportation, brokering, storage, packaging, and distribution.

The importance of collaboration is well documented in the literature (e.g. Alonso \& Liu, 2012; Che et al., 2005; Dollahite, Nelson, Frongillo, \& Griffin, 2005; Griffin \& Frongillo, 2003), yet few studies have sought to understand how collaboration works in local food systems. Those studies that have examined collaboration in local food systems have primarily presented examples of collaborative initiatives (e.g., Conner, King, Kolodinsky, Roche, Koliba, \& Trubek, 2012; Griffin \& Frongillo, 2003; King et al., 2010; Stevenson, Clancy, King, Lev, Ostrom, \& Smith, 2011), examined barriers to collaboration (e.g., Che et al., 2005; Starr et al., 2003; Vogt \& Kaiser, 2008), or identified benefits of collaboration (e.g., Griffin \& Frongillo, 2003; Izumi, Wright \& Hamm, 2010; Wargenau \& Che, 2006). Although valuable contributions to the literature, such studies do not address the motivations of different parties to participate in collaborative initiatives. Moreover, the studies do not address how each party might bene- 
fit differently from a collaborative initiative. Regional food stakeholders have limited resources (e.g., time, money) that may inhibit their collaborative efforts (Starr et al., 2003). Stakeholders engaging in collaboration initiatives need to know that the resources they expend will ultimately provide beneficial outcomes that are important to them.

Discussions about the benefits of collaboration are important, but their utility is limited without a better understanding of how the different parties value those benefits. Because food systems have multiple players, and each player invests different levels of resources in a collaborative initiative, it stands to reason that each party places varying levels of value on the resulting outcomes. For example, farmers and farmers' market managers might work together on any number of collaborative initiatives within a local food system. Each of these initiatives, if successful, will likely generate positive outcomes, but because each participant has unique objectives, the farmers and the market managers will value those outcomes differently. Therefore each party will experience different levels of motivation to participate in any particular collaborative initiative. Collaboration is likely to occur when each participant has at least three things: an opportunity to collaborate, the resources needed to contribute to the collaboration, and the motivation to collaborate. With a better understanding of the motivations different food system players have to collaborate within local food systems, collaborative initiatives will have a better chance of maximizing positive outcomes for all involved, and therefore will be more likely to lead to the success of the food system.

\section{Study Area}

The location of this study is in southeast Michigan (defined as Livingston, Macomb, Monroe, Oakland, St. Clair, Washtenaw, and Wayne counties, all in southeast Michigan) and was selected for several reasons. First, a local report focused on the Oakland County Farmers Market conducted in 2011 highlighted the need for a more in-depth analysis of the area and the local government's role in the development and support for a regional food system. As a result of that report, local government officials were interested in learning more about the specific barriers and facilitators of food system collaboration in the region. Additionally, southeast Michigan is the setting for several ongoing local food initiatives involving numerous stakeholders. Consequently, the region offers a relatively large population of potential subjects for a study of collaboration. Moreover, there is evidence that collaborative initiatives in southeast Michigan could be improved for various agri-food system entities (Che, Veeck, \& Veeck, 2005), so the initiatives themselves would benefit from any findings that would help to make collaboration in the region more effective.

The U.S. state of Michigan is widely known for its agricultural diversity, being second in the U.S. only to California in diversity, and it is home to various regions where agriculture remains a significant segment of the economy. The agriculture sector employs over one million Michigan residents and contributes over US $\$ 73$ billion to the state's economy (U.S. Department of Agriculture [USDA], 2010-2011). The southeast part of Michigan, which includes the Detroit metropolitan area and surrounding suburbs, is the most heavily populated and diverse part of the state.

Southeast Michigan encompasses many urban spaces that are close to rural and agricultural land, which is considered to be a strength for the development of a regional food system (Martinez et al., 2010). The area is currently working to develop a sustainable regional food system in spite of common infrastructural difficulties and a growing number of local food networks and food hubs that are not well integrated (Barham, Tropp, Enterline, Farbman, Fisk, \& Kiraly, 2012). Southeast Michigan is home to two growing food hubs, Detroit Eastern Market Corporation and Harvest Michigan in Clarkston, Michigan, which are poised to help meet and grow the demand for local foods. Because population in this area is projected to increase for every county except Wayne County (Southeast Michigan Council of Governments [SEMCOG], 2012), the consumer base for growing demand and bolstering support for a regional food system is expected to increase. Complementing this increasing consumer base is the growing interest and development of farm-to-institution (FTI) programs. According to a study on FTIs in Southeast 
Michigan, of the 80 institutions surveyed more than 75 percent purchased local foods in the previous year (Matts \& Colasanti, 2013). Interest in farm-to-school programs is also on the rise in the region (Matts \& Smalley, 2013), as well as interest in the potential of developing urban gardening and farming enterprises (Score \& Young, 2008), kitchen incubators, grain processing facilities (Buck, Kaminski, Stockmann, \& Vail, 2007), and additional businesses in the agri-food system.

The purpose of this exploratory study is to examine the suitability of expectancy theory to understand the factors that lead to motivation to collaborate among different types of local food system players. Expectancy theory (Vroom, 1964) is a motivation theory that is well suited for this context as it takes into account that different players may experience different levels of motivation for participation in collaborative initiatives, because the outcomes of those initiatives will be valued differently depending on each player's objectives.

Among the stakeholders that compose a regional food system, farmers and farmers' market managers were selected because the region has seen an increase in farmers' markets and a decline in agricultural land (SEMCOG, 2003). This contributes to an imbalance in supply and demand that potentially creates difficulty for both groups of stakeholders, thus making the need for effective collaboration increasingly important. These two entities also play a prominent role in local food systems, and it was hoped that there would be enough subjects from each group to provide useful results. The study itself uses expectancy theory to examine the motivation of farmers and farmers' market managers to participate in collaborative initiatives common to a local food system. Specifically, this study addresses the following research questions as guided by this theory:

1. How do farmers and farmers' market managers differ in their belief that collaboration will lead to positive outcomes?

2. How do farmers and farmers' market managers differ in their perceived value of the outcomes that result from collaboration?

3. What are the perceived barriers to collaboration for farmers and farmers' market

\section{managers?}

The answers to these questions will help to understand differences in motivation that farmers and market managers have toward collaborating with one another. Findings could provide insights into strengthening collaboration between these two parties and could provide a framework for better understanding how motivation to collaborate may vary among different local food system players, an important step in developing more effective collaborative relationships and stronger, more sustainable food networks.

\section{Literature Review}

The theoretical and research literature on collaboration in local food networks has increased in recent years, but still does not adequately address the need for research in this area. Literature relating to expectancy theory has been used to study motivation in many contexts, but this theory has yet to be used in studies involving collaboration. Literature on collaboration does not present a general theory of collaboration that can be used for this study, but remains malleable to the "contexts, interests and applications to those who are defining it" (Elliott, 2007, p. 30). Therefore, literature was reviewed from agriculture, social sciences, and business and management research. Related literature was organized into the following topical areas: collaboration, motivations among local food stakeholders, and expectancy theory.

\section{Collaboration}

Organizations in many industries have long sought to improve their performance through strategic alliances with other organizations (Doz \& Hamel, 1998; Wargenau \& Che, 2006). These partnerships can occur horizontally (e.g., farmers' markets working together on an initiative) or vertically (e.g., farmers collaborating with schools as part of a farm-to-school program) (Michael, 2007; Mitchell $\&$ van der Linden, 2010). Collaboration involves relationships with many levels of communication, joint strategies, and accomplishments that contribute to a common product or goal (Bronstein, 2003; Dollahite et al., 2005). Considering the many ways in which collaboration is central to local food sys- 
tems, the emergence of collaborative organizational structures such as food hubs, local food networks, and communities of practice around food systems comes as no surprise. Despite some differences in how these concepts logistically operate, the overarching similarity is that they all focus on developing partnerships and collaborations to advance a shared mission or purpose concerning local agriculture and food.

One line of collaboration research has identified barriers to collaboration. Che et al. (2005) found that because they are typically geographically isolated and often lack certain marketing skills, farmers who interact directly with consumers have a greater need to participate in collaborative marketing initiatives, compared to those who grow commodity crops. Vogt and Kaiser (2008) identified lack of infrastructure, financial support, and institutional support as barriers that inhibit collaborative efforts even if local food system stakeholders are willing to collaborate. For the parties that do engage in collaborative efforts, activities are often limited due to issues such as reliability, convenience, seasonal constraints, and price (Starr et al., 2003).

The few studies that explore collaboration in local food systems typically focus on supply or value chains, likely because this is a common approach of studies of collaboration in conventional and commodity-based agriculture (Bloom \& Hinrichs, 2011). Supply chain analysis addresses five major areas: (1) the nature of the production process; (2) the economic and social organization of food production; (3) the use and management of labor; (4) the role of scientific research and extension activities; and (5) the organization of marketing and distribution activities (Buttel, Larson, \& Gillespie, 1990, as cited by Murdoch, 2000). Although these areas focus on important collaborative activities, successful collaboration also requires an understanding of relational and motivational issues among local food system stakeholders (Matopoulos et al., 2007).

In their work on values-based supply chains, Stevenson and Pirog (2008) identify trust as an important component in successful value-chain relationships. Without trust, a successful and lasting collaborative relationship is unsustainable.
Others have also mentioned the importance of trust in collaborative relationships (e.g., Ambrose, Marshall \& Lynch, 2010); however, there has been no research into how trust is fostered among local food system stakeholders, and, more importantly, how it impacts the motivation of local food system stakeholders to collaborate.

Although few studies have focused on collaboration in local food systems, even fewer studies have addressed the motivation to collaborate in local food systems. In an effort to identify the motivations for collaboration in a wine region in Michigan, Wargenau and Che (2006) interviewed winery owners and identified benefits to collaboration for marketing and promotion, such as increased publicity and pooling money for promotional initiatives that none of the wineries could do on their own. Alonso and Liu (2012) found that collaborating in a local food network could help to bring recognition to a region, thereby building the region's brand. Although these studies make valuable contributions by identifying benefits of collaboration, they do not specifically address the factors that impact motivation to collaborate.

\section{Motivation Among Local Food System Players} Izumi, Wright, and Hamm (2010) examined farmers' motivations to participate in farm-to school programs and found that they sold their products to schools to diversify their distribution channels and for social reasons (e.g., to improve children's access to nutritious foods and support the local community). Conner et al. (2012) also examined farmers' motivation for involvement with farm-toschool programs and similarly found that their participation was driven by both economic and social motivations.

Building on the notion that farmers are at least somewhat motivated by factors other than economic ones, several studies have examined farmers' motivations toward environmental activities such as organic farming, compliance with environmental regulations, and land protection. Peterson, Barkley, Chacon-Casante, Kastens, Marchant, and Bosch (2012) found that organic grain and soybean farmers in the U.S. were motivated to produce organic products by multiple factors, including economic and environmental ones, and that younger farmers 
were more likely to be motivated by environmental and lifestyle factors than older farmers. Ryan, Erickson \& De Young (2003) surveyed Michigan farmers to learn about their motivations for adopting conservation practices and found that rather than economic reasons, farmers were intrinsically motivated to adopt conservation practices because of their attachment to the land. In another study that examined economic and intrinsic motivations for farmers' stewardship behaviors, Chouinard, Paterson, Wandschneider, and Ohler (2008) found that farmers are willing to forego some financial benefits in order to engage in ecofriendly farm practices. All of these studies provide evidence that in addition to economic motivations, social and environmental ones also influence farmer behavior. Because the environmental and social benefits of local food networks are well known, these studies are helpful in understanding farmers' motivations to participate in local food systems.

Although the above studies have advanced the understanding of important topics such as the benefits of collaboration and the identification of farmers' motivations for environmental behaviors, they do not provide a theoretical explanation for the motivations that drive behaviors. This study uses the expectancy theory of motivation (Vroom, 1964) to understand the motivations that drive different parties' participation in collaborative initiatives.

\section{Expectancy Theory}

Expectancy theory uses intrinsic and extrinsic motivators to explain the driving force to make certain choices to achieve a particular goal (Friedman, Cox, \& Maher, 2008). Although originally used to understand the motivation of individuals in the workplace (Vroom, 1964), expectancy theory has also been used to understand the behavior of organizations (e.g., Chen \& Miller, 1994; Mobley \& Meglino, 1977; Wei, Frankwick \& Nguyen, 2012).

The theory involves two major concepts: expectancy and valence (Andereck, McGehee, Lee, \& Clemmons, 2012). Expectancy is the belief that effort, or dedication of resources, will lead to a certain outcome or goal (Lawler, 1973). Valence is the value a person places on the outcome (Hancock, 1995; Vroom, 1964). Together, expectancy and valence combine to determine motivation toward a task or initiative (Isaac, Zerbe, \& Pitt, 2001). According to the theory, if an individual or organization does not believe that applying resources toward a specific task or initiative will result in a certain outcome, or if they do not value that outcome, they will be less motivated to participate in the initiative. This principle demonstrates the value of expectancy theory in understanding motivation to collaborate in local food systems. Any particular collaborative initiative in a local food system will require some level of resource investment (likely time and/or money) from multiple parties. However, if one party is not as convinced that the initiative will lead to the stated outcome, it follows that they will be less motivated to contribute, thereby weakening the chance of success of the initiative. Additionally, even if each party believes that the initiative will deliver the stated outcome(s), if a party does not value that outcome as much, according to expectancy theory, it will be less motivated to contribute resources to the initiative. Researchers have identified the benefits of collaboration in local food systems; however, there has been no recognition that those benefits might be valued differently by different players in a local food system (for instance, farmers and farmers' market managers).

\section{Method}

\section{Instruments}

The researchers collected data by administering two survey questionnaires: one given to farmers and one to farmers' market managers (hereafter referred to as "FM managers"). (See the FM managers' survey in the Appendix.) The surveys were similar and only varied from each other in language and choices that were only appropriate for the specific audience. The instruments were based on previously published study instruments that used expectancy theory (for example, Turcan, 2010) that were modified to respond to the context of this research. Face validity involves subjectively evaluating a survey instrument to ensure it covers the concept it purports to measure. To ensure face 
validity for this study, both survey instruments were reviewed by Michigan State University (MSU) faculty, independent subject matter experts, and graduate students. Vroom's (1964) expectancy theory is used as the framework for the questionnaire, with the goal of understanding participants' motivations to collaborate with other local food system stakeholders.

The surveys each contained 25 questions with 23 Likert-type questions with predefined choices. Because using a participant's own outcomes is suggested when using expectancy theory to measure motivation (Mitchell, 1974), researchers conducted a review of literature relevant to local/regional food systems and collaboration to identify common outcomes, such as increased revenue, increased time for other business activities, increased sense of community, improved relationships among the food system community, and improved reputation (Ambrose et al., 2010; Feenstra, 1997; Pirog \& Bregendahl, 2012; Stevenson \& Pirog, 2008). These outcomes were used to create scales to measure expectancy and valence.

Questions were designed to measure a participant's belief that engaging in collaborative initiatives with other food system stakeholders will lead to a desired outcome (expectancy). A five-point Likert-type scale was used with numerical values ranging from one to five and value description anchors ranging from never to every time. Variables were analyzed using frequencies and descriptive statistics. Mean values were computed for all participants for each variable (i.e., expectancy) and t-tests were used to compare means. Cronbach's alpha was used to measure the reliability of the expectancy and valence scales for both the farmer and FM manager surveys. A Cronbach's alpha score of .70 or higher is considered an acceptable reliability level. The valence scale for farmers had a value of .87 and the expectancy scale had a value of .77. The valence scale for FM managers had a value of .83 and the expectancy scale had a value of .75 .

\section{Study Participants}

Researchers tried to engage as many farmers and FM managers in the region as possible to participate in the study. A list of all farmers and farmers' markets located within the study area was compiled using Internet searches of databases including, but not limited to, the Michigan Farmers' Market Association (MIFMA) database, the Local Harvest database, and Real Time Farms.com. Additionally, researchers received and consolidated contact lists from MSU Extension, Oakland County, and Detroit's Eastern Market Corporation. The final list included 147 farms and each of the 90 farmers' markets in the study area. All the farmers and FM managers from these were invited to participate in this study.

Because of the limited number of subjects available to participate in this study, it was important to achieve as strong a response rate as resources would allow. Other studies that surveyed farmers have experienced low response rates (e.g., 21.9 percent by Peterson et al., (2012) and 20 percent by Ryan, Erickson, \& De Young, (2003)). In a study investigating the notoriously low survey response rates of farmers, Pennings, Irwin, and Good (2002) found that providing incentives, creating shorter surveys, and choosing the right time of year can help to increase response rates. The survey for this study was developed to be as short and concise as possible, but there was very little flexibility for changing the study period and there were not enough financial resources to offer meaningful incentives. To encourage responses, researchers used the Dillman Total Design method (Dillman, Smyth, \& Christian, 2009) to contact farmers and farmers' markets in the study area. Participants were sent a paper letter or an email introducing the study, followed by the survey with a stamped return envelope three days later. A reminder postcard was sent five days later, and a final contact, which included a final letter of invitation and an additional copy of the survey with a stamped return envelope was sent seven days after the postcard was distributed. Using this method, researchers achieved an overall response rate of 33 percent. Although this is better than many studies, it was lower than researchers hoped for, especially given the small sample size.

\section{Results}

A total of 237 surveys were sent out, 90 to FM managers and 147 to farmers; 21 of the invitations 
to farmers were returned as undeliverable. The response rate was 38 percent for FM managers and 30 percent for farmers. Among the farmer respondents, the majority were male ( 74.3 percent) and the average years of experience in farming was 17.5 years. Among the FM manager respondents, the majority were female $(87.5$ percent) with an average of 4.6 years of experience as a FM manager. The majority of both groups were over the age of 50 .

Regarding education, 47.3 percent of farmers had at least a bachelor's degree, compared to 72.7 percent of FM managers. (See Table 1 for all respondent demographics.) Some of these differences among the two groups, such as gender, are striking and as will be discussed later, make attribution of the reasons for any differences in motivation impossible to understand with certainty.

Subjects were asked how important they think collaboration is to local food movements. More FM managers than farmers felt that collaboration is more important, with 71 percent of FM managers indicating that collaboration is important or very important to local food movements, compared to just 47.2 percent of farmers.

To help understand the extent to which farmers and FM managers face different obstacles to collaboration, subjects were asked to indicate the barriers that inhibit their partnering with other food system stakeholders. Overall, farmer respondents indicated a greater number of barriers $(\mathrm{M}=$ 2.12) than did FM managers $(\mathrm{M}=1.67)$ when it comes to collaborating with other food system stakeholders (see Table 2). The most frequently cited barrier for both farmers and FM managers was lack of time for collaboration. Of the reasons provided on the survey, the least cited barrier to collaboration with other food system stakeholders was "Other collaborators would benefit more than

\section{Table 1. Respondent Demographics}

\begin{tabular}{lrc}
\hline & $\begin{array}{c}\text { Farmers } \\
(N=37)\end{array}$ & $\begin{array}{c}\text { Farmers' Market } \\
\text { Managers } \\
(N=33)\end{array}$ \\
\hline Male & $74.3 \%$ & $12.5 \%$ \\
\hline Female & $25.7 \%$ & $87.5 \%$ \\
\hline Age $20-29$ & & \\
30-39 & $10.8 \%$ & $16.0 \%$ \\
$40-49$ & $5.4 \%$ & $9.7 \%$ \\
$50-59$ & $16.2 \%$ & $19.4 \%$ \\
$60+$ & $48.6 \%$ & $32.3 \%$ \\
\hline Years of Experience (Average) & $19.0 \%$ & $22.6 \%$ \\
\hline Education Level & 17.5 & 4.6 \\
$\quad$ Less than 12 years & & \\
High School/GED & $5.3 \%$ & $0 \%$ \\
Some College & $15.8 \%$ & $6.1 \%$ \\
College Graduate & $31.6 \%$ & $21.2 \%$ \\
$\quad$ Advanced Degree & $34.2 \%$ & $42.4 \%$ \\
\hline
\end{tabular}

I/the market would," suggesting that a concern about "freeloaders" is not a major barrier to collaboration among respondents. All of the barriers provided were identified by a higher percentage of farmers than FM managers. Three barriers in particular were identified by a significantly higher percentage of farmers than FM managers: "The costs outweigh the benefits"; "I don't benefit enough from partnering/collaborating with others"; and "Depending on others is too risky."

Both farmers and FM managers were asked about their experience participating in a variety of collaborative initiatives (see Table 3). For farmers, participation in collaborative initiatives is largely

\section{Table 2. Respondent Barriers to Collaborating}

\begin{tabular}{lrc}
\hline & $\begin{array}{c}\text { Farmers } \\
(N=33)\end{array}$ & $\begin{array}{c}\text { Farmers' Market } \\
\text { Managers } \\
(N=24)\end{array}$ \\
\hline I don't have the time & $39.5 \%$ & $38.2 \%$ \\
I am not sure of the benefits & $34.2 \%$ & $26.5 \%$ \\
Depending on others is too risky & $34.2 \%$ & $2.9 \%$ \\
The costs outweigh the benefits & $31.6 \%$ & $11.8 \%$ \\
I don't benefit enough from & $28.9 \%$ & $5.9 \%$ \\
partnering/collaborating with others & $10.5 \%$ & $20.6 \%$ \\
Other & $7.9 \%$ & $5.9 \%$ \\
Other collaborators would benefit more & 2.12 & 1.67 \\
\hline Mean Number of Barriers Cited Per Respondent & &
\end{tabular}


Table 3. Participation in Collaborative Initiatives

\begin{tabular}{lcc}
\hline & $\begin{array}{c}\text { Farmers } \\
(N=38)\end{array}$ & $\begin{array}{c}\text { Farmers' Market } \\
\text { Managers } \\
\text { (N=34) }\end{array}$ \\
\hline $\begin{array}{l}\text { Selling product at a farmers' market } \\
\begin{array}{l}\text { Participating or supporting an event (financially or } \\
\text { nonfinancially) to promote yourself or other food }\end{array}\end{array}$ & $\begin{array}{l}60.5 \% \\
\text { system stakeholders }\end{array}$ & $61.8 \%$ \\
$\begin{array}{l}\text { Actively advocating for policy change that supports } \\
\text { sustainable farming or agriculture }\end{array}$ & $28.9 \%$ & $23.5 \%$ \\
$\begin{array}{l}\text { Engaging in or supporting research (financially or } \\
\text { nonfinancially) in support of local and sustainable }\end{array}$ & $10.5 \%$ & $29.4 \%$ \\
$\begin{array}{l}\text { food systems } \\
\text { Other }\end{array}$ & $10.5 \%$ & $2.9 \%$ \\
$\begin{array}{l}\text { Participating in local food policy councils } \\
\text { Combining product with other farmers to sell to }\end{array}$ & $7.9 \%$ & $23.5 \%$ \\
larger local buyers (e.g., food hubs) & $5.3 \%$ & $\mathrm{n} / \mathrm{a}$ \\
$\begin{array}{l}\text { Opening your market venue for others to use } \\
\text { Helping farmers combine their product to sell to }\end{array}$ & $\mathrm{n} / \mathrm{a}$ & $47.1 \%$ \\
larger local buyers (e.g., institutional buyers) & $\mathrm{n} / \mathrm{a}$ & $14.7 \%$ \\
\hline
\end{tabular}

cent), and actively advocating for policy change that supports sustainable farming or agriculture (28.9 percent).

FM managers indicated participation in a wider range of collaborative initiatives, with the highest number indicating that they had participated in or supported events (financially or nonfinancially) to promote themselves or other food system stakeholders.

To measure the concept of expectancy (whether investment of resources toward collaboration would lead to positive outcomes), we presented subjects with a list of positive outcomes that might result from collaboration with other local food system players. Subjects were asked to indicate how often they

would expect to experience each outcome as a focused in three areas: selling product at a farmers' market (60.5 percent), engaging or supporting an event (financially or nonfinancially) to promote themselves or other food system players (42.1 per-

\begin{tabular}{|c|c|c|c|c|c|}
\hline & $\begin{array}{l}\text { Mean and } \\
\text { Standard } \\
\text { Deviation }\end{array}$ & $\begin{array}{l}\text { Farmers } \\
(N=34)\end{array}$ & $\begin{array}{c}\text { Farmers' Market } \\
\text { Managers } \\
(N=32)\end{array}$ & $\mathrm{t}(d f=64)$ & $p$ \\
\hline \multirow{2}{*}{ Contributing to community } & $\mathrm{M}$ & 3.80 & 4.35 & \multirow{2}{*}{-2.669} & \multirow{2}{*}{.010} \\
\hline & SD & .816 & .573 & & \\
\hline \multirow{2}{*}{ Strengthening relationships } & $\mathrm{M}$ & 3.58 & 3.87 & \multirow{2}{*}{-1.061} & \multirow{2}{*}{.294} \\
\hline & SD & .830 & 1.1014 & & \\
\hline \multirow{2}{*}{$\begin{array}{l}\text { Increasing knowledge of local food } \\
\text { systems }\end{array}$} & $\mathrm{M}$ & 3.54 & 4.26 & \multirow{2}{*}{-3.348} & \multirow{2}{*}{.002} \\
\hline & SD & .833 & .619 & & \\
\hline \multirow{2}{*}{ Spending less time marketing } & $\mathrm{M}$ & 3.38 & 2.91 & \multirow{2}{*}{2.542} & \multirow{2}{*}{.015} \\
\hline & SD & .647 & .596 & & \\
\hline \multirow{2}{*}{$\begin{array}{l}\text { Increasing return on investment (financial } \\
\text { or nonfinancial) }\end{array}$} & $\mathrm{M}$ & 3.29 & 3.43 & \multirow{2}{*}{-.595} & \multirow{2}{*}{.555} \\
\hline & SD & .751 & .896 & & \\
\hline \multirow{2}{*}{ Having more time } & $\mathrm{M}$ & 3.29 & 3.04 & \multirow{2}{*}{.980} & \multirow{2}{*}{.332} \\
\hline & SD & .624 & 1.065 & & \\
\hline \multirow{2}{*}{ Increased work effectiveness } & $\mathrm{M}$ & 3.08 & 3.61 & \multirow{2}{*}{-2.218} & \multirow{2}{*}{.032} \\
\hline & SD & .640 & .988 & & \\
\hline \multirow{2}{*}{ Total Expectancy } & $M$ & 3.45 & 3.60 & \multirow{2}{*}{-2.096} & \multirow{2}{*}{.042} \\
\hline & $S D$ & .253 & .218 & & \\
\hline
\end{tabular}


Table 5. Motivation to Collaborate: Valence

\begin{tabular}{|c|c|c|c|c|c|}
\hline & $\begin{array}{l}\text { Mean and } \\
\text { Standard } \\
\text { Deviation }\end{array}$ & $\begin{array}{l}\text { Farmers } \\
(N=25)\end{array}$ & $\begin{array}{c}\text { Famers' Market } \\
\text { Managers } \\
(N=23)\end{array}$ & $\mathrm{t}(d f=46)$ & $p$ \\
\hline \multirow{2}{*}{ Contributing to community } & $\mathrm{M}$ & 3.91 & 4.13 & \multirow{2}{*}{-1.098} & \multirow{2}{*}{.276} \\
\hline & SD & .887 & .670 & & \\
\hline \multirow{2}{*}{ Strengthening relationships } & $\mathrm{M}$ & 3.79 & 3.94 & \multirow{2}{*}{-.686} & \multirow{2}{*}{.495} \\
\hline & SD & .808 & .854 & & \\
\hline \multirow{2}{*}{$\begin{array}{l}\text { Increasing knowledge of local food } \\
\text { systems }\end{array}$} & $\mathrm{M}$ & 3.59 & 4.16 & \multirow{2}{*}{-3.239} & \multirow{2}{*}{.002} \\
\hline & SD & .701 & .723 & & \\
\hline \multirow{2}{*}{ Spending less time marketing } & $\mathrm{M}$ & 3.53 & 3.40 & \multirow{2}{*}{.428} & \multirow{2}{*}{.670} \\
\hline & SD & 1.107 & 1.303 & & \\
\hline \multirow{2}{*}{$\begin{array}{l}\text { Increasing return on investment } \\
\text { (financial or nonfinancial) }\end{array}$} & $\mathrm{M}$ & 3.76 & 3.97 & \multirow{2}{*}{-1.126} & \multirow{2}{*}{.264} \\
\hline & SD & .708 & .765 & & \\
\hline \multirow{2}{*}{ Having more time } & $\mathrm{M}$ & 3.82 & 3.77 & \multirow{2}{*}{.174} & \multirow{2}{*}{.863} \\
\hline & SD & 1.185 & 1.165 & & \\
\hline \multirow{2}{*}{ Increased work effectiveness } & $\mathrm{M}$ & 3.65 & 3.84 & \multirow{2}{*}{-.787} & \multirow{2}{*}{.434} \\
\hline & SD & 1.041 & .987 & & \\
\hline \multirow{2}{*}{ Total Valence } & $M$ & 3.74 & 3.89 & \multirow{2}{*}{-1.124} & \multirow{2}{*}{.265} \\
\hline & $S D$ & .349 & .692 & & \\
\hline
\end{tabular}

result of collaborating, on a five-point scale, with one being "Never," five being "Every Time," and "Sometimes" in the middle.

For farmers, the mean score for each outcome was above 3 , suggesting that farmers thought that collaboration could lead to each of the presented positive outcomes at least sometimes (see Table 4). The initiatives with the highest expectancy for farmers were contributing to their community (M $=3.80$ ) and strengthening their relationships with other food system players $(\mathrm{M}=3.58)$. The outcome with the lowest expectancy for farmers was increased work effectiveness $(\mathrm{M}=3.08)$.

FM managers showed mean scores above 3.0 for all but one outcome: spending less time marketing $(\mathrm{M}=2.87)$, suggesting that FM managers would not expect collaboration to lead to this outcome very often. The outcomes with the highest expectancy among for FM managers are contributing to their community $(M=4.35)$, and increasing their knowledge of local food system $(\mathrm{M}=$ 4.22).

We used T-tests to compare the mean scores that farmers and FM managers reported for each of the collaboration outcome items presented in the survey. Although we were concerned that the low number of responses $(\mathrm{N})$ might make it impossible to discern significant differences, the variance in the means between the farmers and FM managers for four of the seven items were found to be statistically significant. Moreover, the variance in the means for the overall total expectancy scores between the two groups was also statistically significant.

To measure valence (the value placed on an outcome), we asked subjects to indicate the extent to which each of the positive outcomes mentioned above would help his or her farm or farmers' market. Subjects selected from a five-point scale with one being "Not Helpful," five being "Very Helpful," and "Neutral" in the middle.

Both farmers and FM managers had a mean score over three for each possible outcome presented suggesting that both groups identified at least some value for each outcome (see Table 5). FM managers had a slightly higher overall average $(\mathrm{M}=3.89)$ than famers $(\mathrm{M}=3.74)$; however, $\mathrm{t}-$ tests did not show a significant difference between these means. The two outcomes with the highest valence for farmers were contributing to their community $(\mathrm{M}=3.91)$, and having more time ( $\mathrm{M}$ = 3.82). The outcomes with the most valence for 
Table 6. Motivation to Collaborate: Expectancy $\times$ Valence

\begin{tabular}{|c|c|c|c|c|c|}
\hline & $\begin{array}{l}\text { Mean and } \\
\text { Standard } \\
\text { Deviation }\end{array}$ & $\begin{array}{l}\text { Farmers } \\
(N=25)\end{array}$ & $\begin{array}{c}\text { Farmers' Market } \\
\text { Managers } \\
(N=23)\end{array}$ & $\mathrm{t}(d f=46)$ & $p$ \\
\hline \multirow{2}{*}{ Contributing to community } & $\mathrm{M}$ & 16.21 & 17.61 & \multirow{2}{*}{-.704} & \multirow{2}{*}{.485} \\
\hline & SD & 7.690 & 5.774 & & \\
\hline \multirow{2}{*}{ Strengthening relationships } & M & 14.17 & 15.22 & \multirow{2}{*}{-.616} & \multirow{2}{*}{.541} \\
\hline & SD & 5.331 & 6.135 & & \\
\hline \multirow{2}{*}{$\begin{array}{l}\text { Increasing knowledge of local food } \\
\text { systems }\end{array}$} & M & 13.96 & 17.22 & \multirow{2}{*}{-2.232} & \multirow{2}{*}{.031} \\
\hline & SD & 4.695 & 5.090 & & \\
\hline \multirow{2}{*}{ Spending less time marketing } & M & 12.09 & 10.30 & \multirow{2}{*}{1.039} & \multirow{2}{*}{.304} \\
\hline & SD & 5.861 & 5.772 & & \\
\hline \multirow{2}{*}{$\begin{array}{l}\text { Increasing return on investment } \\
\text { (financial or nonfinancial) }\end{array}$} & $\mathrm{M}$ & 12.52 & 13.39 & \multirow{2}{*}{-.570} & \multirow{2}{*}{.572} \\
\hline & SD & 5.053 & 5.289 & & \\
\hline \multirow{2}{*}{ Having more time } & M & 13.09 & 11.87 & \multirow{2}{*}{.695} & \multirow{2}{*}{.491} \\
\hline & SD & 4.870 & 6.851 & & \\
\hline \multirow{2}{*}{ Increased work effectiveness } & $\mathrm{M}$ & 11.71 & 13.3913 & \multirow{2}{*}{-2.091} & \multirow{2}{*}{.042} \\
\hline & SD & 2.866 & 2.641 & & \\
\hline \multirow{2}{*}{ Total Motivation } & $\mathrm{M}$ & 12.77 & 14.096 & \multirow{2}{*}{-2.294} & \multirow{2}{*}{.027} \\
\hline & SD & 2.062 & 1.892 & & \\
\hline
\end{tabular}

FM managers were increased knowledge of local food systems $(\mathrm{M}=4.16)$ and contributing to their community $(\mathrm{M}=4.13)$.

According to expectancy theory, motivation is the result of the combination of expectancy and valence. Table 6 shows the result of multiplying the mean scores for expectancy by the mean scores of valence (as is consistent with other uses of expectancy theory measures), the difference in these numbers between farmers and FM managers, and the results of $\mathrm{t}$-tests to measure the significance of these differences. Results show that contributing to community, increasing knowledge of local food systems, and strengthening relationships are the outcomes that generate the highest values of total motivation for each group. Two (increasing knowledge of food systems, and contributing to community) show the greatest discrepancy between the farmers and FM managers, but the t-test only showed a significant difference in the means for increasing knowledge of food systems. Also, the ttest showed a significant difference between the mean total motivation scores for the famers and FM managers, suggesting that with regard to the outcomes presented in the survey, farmers are less motivated to collaborate than FM managers.

\section{Discussion}

This study examined the motivations to collaborate among two different groups of players in a local food system through the theoretical lens of expectancy theory. Because collaboration relies on the contributions of different parties that have different objectives, expectancy theory is particularly well suited to understand motivation in this context. The expectancy component of the theory can help understand whether different parties believe a particular collaborative initiative will result in positive outcomes. The valence component shows the value different parties place on those outcomes. Together these two components provide insight to the motivation to collaborate on different initiatives.

Results showed that for both groups, the overall scores for valence exceeded the overall scores for expectancy. This suggests that both groups value the potential outcomes of collaboration more than they expect collaboration to lead to those outcomes. Therefore efforts to overcome barriers to collaboration might be more successful if they focus on steps to ensure the success of the collaborative initiatives (or on communicating the likelihood of success) more than on emphasizing the 
value of the outcomes. One challenge in doing this, however, is that the mean overall expectancy levels for each group (as well as the expectancy levels for four of the seven potential outcomes) are statistically different. In other words, farmers and FM managers have different levels of confidence that collaboration will lead to the listed outcomes. These results show the important need for communication between all parties considering collaboration. Effective communication about each party's specific objectives and the potential outcomes of a collaborative initiative can lead to a collaboration that maximizes the motivation for each party.

Collaboration that emphasizes outcomes that both groups value and believe are achievable creates a "win-win" scenario that is more likely to be successful because both parties will be motivated to invest the needed resources. The results of this study showed that collaborative initiatives that have the goals of helping both parties save time, increase their return on investment (ROI), spend less time marketing, contribute to community, and build relationships will have similar levels of motivation among farmers and FM managers because the mean scores for these items are not statistically different. In addition to helping to identify collaborative initiatives that offer these outcomes, understanding each party's motivation can help to convince a skeptical participant to collaborate by communicating anticipated benefits that are valued by the unconvinced party.

This study also shows that certain collaboration outcomes generate different levels of motivation for each party. For instance, FM managers are much more motivated than farmers by collaborative initiatives that result in increased knowledge of local food systems and increased work effectiveness. Farmers, on the other hand, are more motivated than FM managers by initiatives that result in spending less time marketing, though that difference is not statistically significant. Understanding the motivation levels tied to specific outcomes can be useful to anyone trying to encourage collaboration between these groups. Any collaborative initiative has the potential to produce multiple positive outcomes. When attempting to encourage collaboration, however, the outcomes that produce higher motivation levels for a specific group should be emphasized in discussions with that group.

This concept does not necessarily mean that the outcomes that generate different levels of motivation among groups should be downplayed in discussions with those groups. For example, this study showed that FM managers have a statistically higher level of motivation than farmers for collaboration that results in increased knowledge of local food systems. Despite this motivation gap, initiatives that result in increased knowledge of local food systems will still motivate farmers more than most of the other outcomes. Although this might seem contradictory, it is because FM managers have overall higher levels of motivation than farmers for the outcomes that result from collaboration. Therefore, although FM managers might have higher levels of motivation than farmers for collaborations that lead to increased knowledge of local food systems, this outcome is still highly valued by farmers and will likely find high levels of motivation from each party. This may not be the case in situations where parties are concerned about equity, as "free-riding" has been identified as a potential barrier to collaboration in some settings (e.g., Chaudhuri, 2008; Smith, Peirce \& Ricci, 2011). However, the present study showed that freeloaders are not a significant barrier to collaboration in local food systems.

As noted above, FM managers have overall higher levels of motivation for collaboration than farmers. It is certainly possible that farmers are simply less interested in collaboration. In a study of English farmers, Gasson (1973) showed that farmers value their independence and way of life more so than social (collaborative) aspects related to their work. It is also possible that there are other reasons why farmers showed less motivation to collaborate than FM managers. Although the results of this study cannot fully explain this discrepancy, it does reveal some other potential explanations. First, it is possible that other differences among the respondent groups are responsible for the motivation gap. About three-quarters of the farmer respondents were male, while 88 percent of the FM managers were female. It is therefore possible that the different motivation levels 
for collaboration are the result of gender rather than participant group. Similarly the survey showed a large difference in education levels, with 73 percent of FM managers having at least a bachelor's degree compared to 43 percent of farmers. Perhaps the motivation gap is the result of this difference in education levels. This difference in education levels could also explain why FM managers believe they get a better return on investment from research than farmers do. Many studies have shown differences in motivation based on gender and education level, but results vary dramatically based on the context. We were unable to find other studies that examined the effects of gender or education level on motivation to collaborate in a context similar to this study. Lastly, results also showed that FM managers had more experience collaborating than farmers. It is therefore possible that experience with collaboration leads to higher motivation levels for future collaboration. Vroom (1964) explained that there is a difference between anticipated satisfaction with outcomes and actual satisfaction with outcomes. If FM managers with more experience collaborating have found their actual satisfaction with the outcomes to be greater than anticipated, their motivation might be higher as a result.

Although the low overall number of responses limits the ability to conduct further statistical tests to better understand the extent to which differences in motivation are the result of variables such as occupation, gender, education level, or experience with collaboration, the striking differences in these areas are among the most interesting findings from this study. Furthermore, the differences in motivation levels among the groups reinforce that a scale that measures expectancy and valence is able to show motivational differences among groups, even if it is not yet clear from this study which variables are most responsible for those differences. This finding as much as any other is important for informing future research, which could use an expectancy theory-based instrument such as this to further examine the reasons for the motivation differences among groups. Such research could provide important insights into strengthening local food systems by making collaboration more effective.

\section{Implications for Practitioners}

The results of this study highlight the importance of framing and communicating reasons to collaborate differently for specific stakeholders involved in various collaborative initiatives. The following are implications and recommendations that stem from this study for specific food system stakeholders such as farmers, farmers' market organizers and managers, associations, community planners, local government officials, and any other entity that might help to facilitate collaboration between farmers and farmers' markets.

1. Better understanding of which outcomes farmers and FM managers believe are achievable through collaboration, and which outcomes are most valued by each group, can help anyone trying to encourage collaboration in at least three ways. First, this knowledge can help to prioritize which collaborations should be pursued, with the ones most likely to maximize motivation - and therefore most likely to be successful — being pursued first. This is especially important given the time concerns indicated by both groups. Second, better understanding of how each group values specific outcomes can help inform the communication that is used to persuade potential participants to collaborate by emphasizing specific messages important to each group. Third, understanding the gaps in motivation that different groups have for certain outcomes can help those trying to encourage collaboration to adjust expectations about resource commitment to ensure less is expected of those who do not expect to benefit as much from the collaboration.

2. Because farmers cited lack of time as the top barrier to collaboration, those trying to recruit participants for collaborative initiatives should acknowledge the value of farmers' time when trying to encourage collaboration, and emphasize how collaboration could result in time savings.

3. It is important to focus on clearly communicating the benefits of collaboration with farmers, since 34 percent of respondents are not sure of the benefits and 29 percent feel 
they do not benefit from collaborating. Benefits communicated should include benefits to the farmers, the market, the community, and the larger food system region, since "feeling like I'm contributing to my community" was reported as the most valued benefit to collaboration for farmers and nearly the most valued for FM managers.

4. Because FM managers indicated they are motivated to open their market venue for others to use, we suggest that farmers communicate their needs to the markets they participate at and/or sell product at to discern how the market can help farmers grow and develop new products (farmers' second most valued benefit when engaging in collaboration). Some examples of this include the farmers' market setting up an incubator kitchen for farmers to use or rent to develop value added products, or providing a space for farmers to distribute community supported agriculture (CSA) shares to customers, allowing them to diversify their business through a CSA program.

5. Since FM managers reported that their greatest ROI is "engaging in or supporting an event (financially or nonfinancially) to promote themselves or other food system stakeholders," we suggest that farmers pursue support from their local farmers' markets to create events relevant to their needs. For example, since 29 percent of farmers reported that they collaborate by "actively advocating for policy change that supports sustainable farming and agriculture," farmers' markets could be used to host events to increase awareness and support for policy changes within the community.

6. Because both farmers and FM managers reported relatively high mean scores for expectancy, both groups believe their investment in collaboration will lead to positive outcomes. Parties trying to encourage collaboration should therefore ensure that those outcomes are likely to be valued by those collaboration participants.

7. Because over 30 percent of farmers responded that collaboration "is too risky," those championing collaboration should focus on building trust when collaborating. Trust can be built by providing farmers some control when collaborating, or implementing a contract or policy that formalizes outcomes that farmers desire or value.

\section{Implications for Researchers}

1. Future studies could investigate the reasons for the motivation discrepancy related to collaboration that exists between the groups. Additionally, studies could investigate the motivations of other local food network players. Because expectancy theory is a useful lens through which to understand motivation to collaborate in this context, the scales used in this study, which were found to be reliable, could be used in other contexts. Future studies could also investigate whether collaboration is actually producing the intended outcomes, and could evaluate whether the actual outcomes are valued as much as had been anticipated.

2. Because both groups reported low ROI on participating in research, researchers need to do a better job linking the results of their studies to practical and actionable information that can benefit stakeholders in local food networks. Researchers need to be thoughtful about their outreach efforts to ensure that this information reaches and is understood by appropriate stakeholders.

An obvious limitation of this study is the low number of respondents. Although the overall response rate of 33 percent is better than many other surveys in a similar context, the reader must use caution when interpreting the results. Although some of the t-tests showed significant $p$-values, other differences between means (especially those with the higher standard deviations) may have shown significance with a greater number of responses. For this reason, we were cautious, claiming that a lack of statistically significant variation meant that there were no differences between the compared groups. This study, however, was meant to be exploratory, and exploratory studies often have limited generalizability. Therefore, 
despite the low number of respondents, we believe that this study sufficiently serves the purpose of helping to determine that expectancy theory is indeed a worthy theoretical framework for understanding motivation of local food system players to engage in collaboration.

\section{Conclusion}

Collaboration is vital to the success of local food systems; however those who must collaborate have limited time and financial resources to contribute to collaborative initiatives. Because of this, they will not have high motivation to participate in every collaborative initiative that is proposed. For this reason a more strategic approach to collaboration is required to focus opportunities for collaboration on the initiatives that are likely to have the highest levels of motivation among participants. Doing so will help to ensure that food system players find greater value from collaboration, thereby leading to a culture where collaboration is supported. This study provided some insights into the factors that impact the motivation to collaborate for two of the most important players in local food systems: farmers and farmers' market managers. These results can help local food system stakeholders to more wisely implement collaborative initiatives and can ultimately strengthen local food systems.

Equally important, this study showed that by using a survey instrument based on expectancy theory, it is possible to identify variations in motivation among the different participants in collaboration, a concept that has not yet been addressed in the local foods literature. Although it may seem obvious that different players would have different levels of confidence in the likely success of collaborative initiatives (expectancy), and that each player would place different value on the outcomes of those initiatives (valence), sometimes an easy-tograsp framework such as this can help stakeholders improve the effectiveness of something like a collaboration initiative.

\section{Acknowledgments}

We give special thanks to Oakland County Parks and Recreation and the Michigan Economic Development Corporation (MEDC) for their contributions and support in making this research possible. And much gratitude to the many farmers and farmers' market managers for their voluntary participation in this study.

\section{References}

Ambrose, E., Marshall, D., \& Lynch, D. (2010). Buyer supplier perspectives on supply chain relationships. International Journal of Operations \& Production Management, 30(12), 1269-1290. http://dx.doi.org/10.1108/01443571011094262

Alonso, A. D., \& Liu, Y. (2012). Visitors centers, collaboration, and the role of local food and beverage as regional tourism development tools: The case of the Blackwood River Valley in western Australia. Journal of Hospitality \& Tourism Research, 36(4), 517-536. http://dx.doi.org/10.1177/1096348011413594

Andereck, K., McGehee, N. G., Lee, S., \& Clemmons, D. (2012). Experience expectations of prospective volunteer tourists. Journal of Travel Research, 51(2), 130-141. http://dx.doi.org/10.1177/0047287511400610

Barham, J., Tropp, D., Enterline, K., Farbman, J., Fisk, J., \& Kiraly, S. (2012). Regional food bub resource guide. Washington, D.C.: U.S. Dept. of Agriculture, Agricultural Marketing Service. http://dx.doi.org/10.9752/MS046.04-2012

Bloom, J. D., \& Hinrichs, C. C. (2011). Moving local food through conventional food system infrastructure: Value chain framework comparisons and insights. Renewable Agriculture and Food Systems, 26(1), 13-23. http://dx.doi.org/10.1017/S1742170510000384

Bronstein, L. R. (2003). A model for interdisciplinary collaboration. Social Work, 48(3), 297-306. http://dx.doi.org/10.1093/sw/48.3.297

Buck, K., Kaminski, L., Stockmann, D., \& Vail, A. (2007). Southern Michigan community food profile. East Lansing, Michigan: Food System Economic Partnership. Available from http:// fsepmichigan.org/

Chaudhuri, S. (2008). Institutional analysis of stakeholder collaboration in freight movement at the ports of Los Angeles and Long Beach (Doctoral dissertation). Retrieved from ProQuest Dissertations and Theses database. (UMI No. 3311068). 
Che, D., Veeck, A., \& Veeck, G. (2005). Sustaining production and strengthening the agritourism product: Linkages among Michigan agritourism destinations. Agriculture and Human V alues, 22(2), 225-234. http://dx.doi.org/10.1007/s10460-004$\underline{8282-0}$

Chen, M.-J., \& Miller, D. (1994). Competitive attack, retaliation and performance: An expectancy-valence framework. Strategic Management Journal, 15(2), 85102. http://dx.doi.org/10.1002/smj.4250150202

Chouinard, H. H., Paterson, T., Wandschneider, P. R., \& Ohler, A. M. (2008). Will farmers trade profits for stewardship? Heterogeneous motivations for farm practice selection. Land Economics, 84(1), 6682.

Conner, D. King, B., Kolodinsky, J., Roche, E., Koliba, C. \& Trubek, A. (2012). You can know your school and feed it too: Vermont farmers' motivations and distribution practices in direct sales to school food services. Agriculture and Human Values, 29(3), 321332. http://dx.doi.org/10.1007/s10460-012-9357-y

Dillman, D. A, Smyth, J. D., \& Christian, L. M. (2009). Internet, mail, and mixed-mode surveys: The tailored design method. Hoboken, New Jersey: John Wiley \& Sons.

Dollahite, J. S., Nelson, J. A., Frongillo, E. A., \& Griffin, M. R. (2005). Building community capacity through enhanced collaboration in the Farmers Market Nutrition Program. Agriculture and Human Values, 22(3), 339-354. http://dx.doi.org/10.1007/s10460005-6050-4

Doz, Y. L., \& Hamel, G. (1998). Alliance advantage: The art of creating value through partnering. Boston, Massachusetts: Harvard Business School Press.

Elliott, M. A. (2007). Stigmergic collaboration: A theoretical framework for mass collaboration (Doctoral dissertation). University of Melbourne, Australia. Retrieved from http://mark-elliott.net/blog/ wp-content/uploads/2008/07/elliott phd pub 081007.pdf

Feenstra, G. W. (1997). Local food systems and sustainable communities. American Journal of Alternative Agriculture, 12(1), 28-36. http://dx.doi.org/10.1017/S0889189300007165

Friedman, B. A., Cox, P. L., \& Maher, L. E. (2008). An expectancy theory motivation approach to peer assessment. Journal of Management Education, 32(5), 580-612. http://dx.doi.org/10.1177/1052562907310641
Gasson, R. (1973). Goals and values of farmers. Journal of Agricultural Economics, 24(3), 521-542. http://dx.doi.org/10.1111/j.1477-9552.1973. tb00952.x

Griffin, M. R., \& Frongillo, E. A. (2003). Experiences and perspectives of farmers from Upstate New York farmers' markets. Agriculture and Human Values, 20(2), 189-203. http://dx.doi.org/10.1023/A:1024065526440

Hall, C. M., \& Sharples, L. (2008). Future issues and trends: Food events, festivals and farmers' markets. In C. M. Hall \& L. Sharples (Eds.), Food and wine events around the world (pp. 331-348). Oxford: Butterworth Heinemann.

Hancock, D. R. (1995). What teachers may do to influence student motivation: An application of expectancy theory. Journal of General Education, 44(3), 171-179. http://www.jstor.org/stable/27797259

Henneberry, S. R., Whitacre, B., \& Agustini, H. N. (2009). An evaluation of the economic impacts of Oklahoma farmers markets. Journal of Food Distribution Research, 40(3), 64-78.

Herman, D. R., Harrison, G. G. Afifi, A. A., \& Jenks, E. (2008). Effect of a targeted subsidy on intake of fruits and vegetables among low-income women in the Special Supplemental Nutrition Program for Women, Infants, and Children. American Journal of Public Health, 98(1), 98-105. http://dx.doi.org/10.2105/AJPH.2005.079418

Hughes, D. W., Brown, C., Miller, S., \& McConnell, T. (2008). Evaluating the economic impact of farmers' markets using an opportunity cost framework. Journal of Agricultural and Applied Economics, 40(1), 253-265.

Isaac, R. G., Zerbe, W. J., \& Pitt, D. C. (2001). Leadership and motivation: The effective application of expectancy theory. Journal of Managerial Issues, (13)2, 212-226.

Izumi, B. T., Wright, D. W., \& Hamm, M. W. (2010). Market diversification and social benefits: Motivations of farmers participating in farm to school programs. Journal of Rural Studies, 26(4), 374-382. http://dx.doi.org/10.1016/j.jrurstud.2010.02.002

King, R. P., Hand, M. S., DiGiacomo, G., Clancy, K., Gómez, M. I., Hardesty, S. D., Lev, L., \& McLaughlin, E. W. (2010). Comparing the structure, size, and performance of local and mainstream food supply chains (USDA Economic Research Report No. 99). 
Washington, D.C.: USDA. Retrieved from http://www.ers.usda.gov/publications/erreconomic-research-report/err99.aspx

Lawler E. E., III. (1973). Motivation in work organizations. Monterey, California: Brooks/Cole.

Lester, S. R. (2012). Local food actions and motivations in the Highlands neighborbood of Denver, CO (Doctoral dissertation). Retrieved from ProQuest Digital Dissertations. (Order No. 1509231).

Martinez, S., Hand, M. S., Da Pra, M., Pollack, S., Ralston, K., Smith, T., Vogel, S., Clark, S., Tauer, L., Lohr, L., Low, S. A., \& Newman, C. (2010). Local food systems: Concepts, impacts and issues (Economic Research Report No. 97). Washington, D.C.: USDA. Retrieved from http://www.ers.usda.gov/publications/erreconomic-research-report/err97.aspx

Matopoulos, A., Vlachopoulou, M., Manthou, V., \& Manos, B. (2007). A conceptual framework for supply chain collaboration: Empirical evidence from the agri-food industry. Supply Chain Management: An International Journal, 12(3), 177-186. http://dx.doi.org/10.1108/13598540710742491

Matts, C., \& Colasanti, K. (2013). Local food interest by institutions in southeast Michigan: $A$ report for Eastern Market Cooperation. Ann Arbor, Michigan: Center for Regional Food Systems, Michigan State University. Retrieved from http://foodsystems. msu.edu/resources/fti-report-se-mi

Matts, C., \& Smalley, S. (2013). Farm to school in Michigan: 2012 survey shows interest in purchasing local foods continues to grow. Center for Regional Food Systems, Michigan State University. Retrieved from http://foodsystems.msu.edu/resources/fts-2012survey

Michael, E. J. (2007). Development and cluster theory. In E. J. Michael (Ed.), Micro-clusters and networks: The growth of tourism (pp. 21-31). Oxford: Elsevier. http://dx.doi.org/10.1016/B978-0-08-0450964.50007-X

Mitchell, T. R. (1974). Expectancy models of job satisfaction, occupational preference and effort: A theoretical, methodological, and empirical appraisal. Psychological Bulletin, 81(12), 1053-1077. http://dx.doi.org/10.1037/h0037495

Mitchell, R., \& van der Linden, J. (2010). Adding value through cooperation: A study of the New Zealand food and wine tourism network. Paper presented at the 5 th International Academy of Wine Business Research
Conference, Auckland, New Zealand. Retrieved from http://academyofwinebusiness.com/? page $\mathrm{id}=106$

Mobley, W. H., \& Meglino, B. M. (1977). A behavioral choice model of the budget allocation behavior of academic deans. Academy of Management Journal, 20(4), 564-572. http://dx.doi.org/10.2307/255357

Murdoch, J. (2000). Networks - a new paradigm of rural development? Journal of Rural Studies, 16(4), 407-419. http://dx.doi.org/10.1016/S0743$\underline{0167(00) 00022-\mathrm{X}}$

Myles, A., \& Hood, K. (2010). Economic impact of farmers' markets in Mississippi (Publication 2582). Mississippi State, Mississippi: Mississippi State University Extension Service. Retrieved from http://msucares.com/pubs/publications/p2582. pdf

Oberholtzer, L., \& Grow, S. (2003). Producer-only farmers' markets in the Mid-Atlantic region: A survey of market managers. Arlington, Virginia: Henry A. Wallace Center for Agricultural \& Environmental Policy at Winrock International.

O'Hara, J. K. (2011). Market forces: Creating jobs through public investment in local and regional food systems. Cambridge, Massachusetts: Union of Concerned Scientists, Citizens and Scientists for Environmental Solutions. Retrieved from http://www.ucsusa.org/assets/documents/food and_agriculture/market-forces-report.pdf

Otto, D., \& Varner, T. (2005). Consumers, vendors, and the economic importance of Iowa farmers' markets: An economic impact survey analysis. Ames, Iowa: Strategic Economics Group. Retrieved from the Leopold Center for Sustainable Agriculture website: http://www.leopold.iastate.edu/pubs

Pennings, J. M. E., Irwin, S. H., \& Good, D. L. (2002). Surveying farmers: A case study. Applied Economic Perspectives and Policy, 24(1), 266-277. http://dx.doi.org/10.1111/1467-9353.00096

Peterson, H. H., Barkley, A. P., Chacon-Casante, A., Kastens, T. L., Marchant, M. A., \& Bosch, D. J. (2012). The motivation for organic grain farming in the United States: Profits, lifestyle, or the environment? Journal of Agricultural and Applied Economics, 44(2), 137-155. Retrieved from AgEcon Search website: $\underline{\text { http://ageconsearch.umn.edu }}$

Pirog, R., \& Bregendahl, C. (2012). Creating change in the food system: The role of regional food networks in Iowa. East Lansing, Michigan: MSU Center for Regional 
Food Systems. Retrieved from http://foodsystems. msu.edu/resources/creating-change

Racine, E. F., Vaughn, A. S., \& Laditka, S. B. (2010). Farmers' market use among African-American women participating in the Special Supplemental Nutrition Program for Women, Infants, And Children. Journal of the Academy of Nutrition and Dietetics, 110(3), 441-446. http://dx.doi.org/10.1016/i.jada.2009.11.019

Ryan, R. L., Erickson, D. L., \& De Young, R. (2003). Farmers' motivations for adopting conservation practices along riparian zones in a Mid-western agricultural watershed. Journal of Environmental Planning and Management, 46(1), 19-37. http://dx.doi.org/10.1080/713676702

Schumacher, A., Winch, R., \& Park, A. (2009). Fresh, local, affordable: Nutrition incentives at farmers markets, 2009 update. Bridgeport, Connecticut: Wholesome Wave Charitable Ventures.

Score, M., \& Young, J. (2008). Marketplace perception of the economic potential presented by urban gardening in southeast Michigan. Food System Economic Partnership, Project GREEN, Grant \#71-7967. Retrieved from http://fsepmichigan.org/wp-content/uploads/ 2011/09/Economic-Potential-of-UrbanGardening-in-Southeast-Michigan.pdf

Smith, S., Peirce, E., \& Ricci, M. (2011). Equity in group work methodologies. In G. Williams, P. Statham, N. Brown \& B. Cleland (Eds.), Changing demands, changing directions. Proceedings ascilite Hobart 2011 (pp. 1151-1156). Retrieved from http://www.ascilite. org.au/conferences/hobart11/downloads/papers/s mith-concise.pdf

Southeast Michigan Council of Governments [SEMCOG]. (2003). Land use change in southeast Michigan: Causes and consequences. Retrieved from http://www.semcog.org/WorkArea/Download Asset.aspx?id $=760$

SEMCOG. (2012). Community profiles: Southeast Michigan. Retrieved from http://www.semcog. org/data/bycommunity.cfm

Starr, A., Card, A., Benepe, C., Auld, G., Lamm, D., Smith, K., \& Wilken, K. (2003). Sustaining local agriculture: Barriers and opportunities to direct marketing between farms and restaurants in Colorado. Agriculture and Human Values, 20(3), 301321. http://dx.doi.org/10.1023/A:1026169122326

Stevenson, G. W., Clancy, K., King, R., Lev, L., Ostrom, M., \& Smith, S. (2011). Midscale food value chains: An introduction. Journal of Agriculture, Food Systems, and Community Development, 1(4), 27-34. http://dx.doi.org/10.5304/jafscd.2011.014.007

Stevenson, G. W., \& Pirog, R. (2008). Values-based supply chains: Strategies for agrifood enterprises of the middle. In T. A. Lyson, G. W. Stevenson, \& R. Welsh, (Eds.), Food and the mid-level farm (pp. 119143). Cambridge, Massachusetts: MIT Press.

Turcan, M. (2010). Expectancy theory as a predictor of faculty motivation to use a course management system. Retrieved from ProQuest Digital Dissertations. (UMI 3419302.)

U.S. Department of Agriculture [USDA]. (2010-2011). Michigan Agricultural Statistics 2010-2011 [Data File]. USDA-National Agricultural Statistical Service-Michigan Field Office. Retrieved from http://www.nass.usda.gov

Vogt, R. A., \& Kaiser, L. L. (2008). Still a time to act: A review of institutional marketing of regionallygrown food. Agriculture and Human V alues, 25(2), 241-255. http://dx.doi.org/10.1007/s10460-0079106-9

Vroom, V. H. (1964). Work and motivation. New York: Wiley.

Wargenau, A., \& Che, D. (2006). Wine tourism development and marketing strategies in southwest Michigan. International Journal of Wine Business Research, 18(1), 45-60.

Wei, Y., Frankwick, G. L., \& Nguyen, B. H. (2012). Should firms consider employee input in reward system design? The effect of participation on market orientation and new product performance. Journal of Product Innovation Management, 29(4), 546-558. http://dx.doi.org/10.1111/j.15405885.2012.00924.x 
Appendix. Survey Instrument for Farmers' Market Managers

(Note: Some formatting changes were made to fit the layout. No questions were modified.)

\section{Dear Farmer Market Manager,}

I am reaching out to you to collect information that will help create a clear picture of the bridges and barriers for food system players and stakeholders to collaborate in Southeast Michigan.

*You must be 18 years of age or older in order to participate in this survey. Your participation is completely voluntary and you may withdraw your participation at any time. Thank you in advance for being part of this study and helping to strengthen Southeast Michigan's local and regional food systems.

Contact Information for Questions and Concerns:

If you have any questions about your role and rights, such as scientific issues, how to do any part of it, or to report an injury, please contact the research: Crystal Miller, Department of CARRS, Michigan State University, 131 Natural Resources Bldg., 480 Wilson Rd., East Lansing, MI 48824-1115; mill1879@msu.edu; (517) 353-0803.

If you have any questions about your role and rights as a research participant, or would like to register a complaint about this study, you may contact, anonymously if you wish, the MSU's Human Research Protection Programs, at (515) 355-2180, FAX (517) 432-4503, or e-mail irb@msu.edu, or regular mail at Olds Hall, MSU, East Lansing, MI 48824.

By checking the box, I agree to participate in the survey.

\section{1) Please select any of the following activities in which you have partnered/collaborated with other food} system players/sectors (e.g., other farmers' market managers, processors) (Please check all that apply)

\section{Opening your market venue for others to use (i.e. CSA pick-up for farmers)}

Engaging in or supporting an event (financially or non-financially) to promote yourself or other food system players

Engaging in or supporting an event (financially or non-financially) in support of local and sustainable food systems

Helping farmers combine their product to sell to larger local buyers (e.g. institutional buyers)

Participating in local food policy councils

Actively advocating for policy change that supports sustainable farming or agriculture

Other (Please specify):

No, I have not partnered or collaborated with other food system players/sectors

*If you have not partnered/collaborated, please skip to QUESTION 5. 
2) We are interested in the return on investment you receive from collaboration with other food system players/sectors. Please consider the FINANCIAL AND NON-FINANCIAL contributions you have made, as well as the FINANCIAL AND NON-FINANCIAL benefits you have received from collaborating, and rate the investment from a poor return (1) to an excellent return on investment (5).

\begin{tabular}{|c|c|c|c|c|c|}
\hline & $\begin{array}{l}\text { Very Poor } \\
\text { Return on } \\
\text { Investment } \\
1\end{array}$ & 2 & $\begin{array}{l}\text { Neutral } \\
3\end{array}$ & 4 & $\begin{array}{c}\text { Excellent } \\
\text { Return on } \\
\text { Investment } \\
5\end{array}$ \\
\hline Opening your market venue for others to use. & $\square$ & $\square$ & $\square$ & $\square$ & $\square$ \\
\hline $\begin{array}{l}\text { Engaging in or supporting an event (financially or non- } \\
\text { financially) to promote yourself or other food system } \\
\text { players. }\end{array}$ & $\square$ & $\square$ & $\square$ & $\square$ & $\square$ \\
\hline $\begin{array}{l}\text { Engaging in or supporting research (financially or non- } \\
\text { financially) in support of local and sustainable food } \\
\text { systems. }\end{array}$ & $\square$ & $\square$ & $\square$ & $\square$ & $\square$ \\
\hline $\begin{array}{l}\text { Helping farmers to combine their product to sell to } \\
\text { larger local buyers (e.g. institutional buyers). }\end{array}$ & $\square$ & $\square$ & $\square$ & $\square$ & $\square$ \\
\hline Participating in local food policy councils. & $\square$ & $\square$ & $\square$ & $\square$ & $\square$ \\
\hline $\begin{array}{l}\text { Actively advocating for policy change that supports } \\
\text { sustainable farming or agriculture. }\end{array}$ & $\square$ & $\square$ & $\square$ & $\square$ & $\square$ \\
\hline Other (please specify): & $\square$ & $\square$ & $\square$ & $\square$ & $\square$ \\
\hline \multicolumn{6}{|c|}{$\begin{array}{l}\text { 3) Please list the FINANCIAL AND NON-FINANCIAL contributions you have made, or may make, when } \\
\text { collaborating with other food system players: }\end{array}$} \\
\hline \multicolumn{6}{|l|}{ Please share: } \\
\hline
\end{tabular}

\section{4) We are interested in the benefits you expect to see from partnering/collaborating with other food system} players/sectors. Please use the scale below, with one (1) being never and five (5) being almost always.

\section{Partnering/collaborating with other food system players/sectors will...}

\begin{tabular}{|c|c|c|c|c|c|}
\hline & $\begin{array}{c}\text { Never } \\
1\end{array}$ & 2 & $\begin{array}{l}\text { Sometimes } \\
\quad 3\end{array}$ & 4 & $\begin{array}{l}\text { Every Time } \\
5\end{array}$ \\
\hline $\begin{array}{l}\text {... result in me spending less time on marketing the } \\
\text { farmers' market. }\end{array}$ & $\square$ & $\square$ & $\square$ & $\square$ & $\square$ \\
\hline $\begin{array}{l}\text {...allow me to increase the return of investment for } \\
\text { the market (e.g. financial or non-financial). }\end{array}$ & $\square$ & $\square$ & $\square$ & $\square$ & $\square$ \\
\hline $\begin{array}{l}\text {...allow me more time to develop new programs, } \\
\text { events, etc. at the market. }\end{array}$ & $\square$ & $\square$ & $\square$ & $\square$ & $\square$ \\
\hline $\begin{array}{l}\text {...help strengthen my relationships with other food } \\
\text { system players/sectors. }\end{array}$ & $\square$ & $\square$ & $\square$ & $\square$ & $\square$ \\
\hline ...help me feel like l'm contributing to my community. & $\square$ & $\square$ & $\square$ & $\square$ & $\square$ \\
\hline $\begin{array}{l}\text {...increase my knowledge of local food systems so I } \\
\text { can better educate vendors and customers. }\end{array}$ & $\square$ & $\square$ & $\square$ & $\square$ & $\square$ \\
\hline
\end{tabular}

...help me be more effective in my field work. 


\begin{tabular}{|c|c|c|c|c|c|}
\hline \multicolumn{6}{|c|}{$\begin{array}{l}\text { 5) Which of the following benefits would help the farmers' market the most in a partnership/collaboration } \\
\text { with other food system players/sectors? }\end{array}$} \\
\hline & $\begin{array}{c}\text { Not } \\
\text { Helpful } \\
1\end{array}$ & 2 & $\begin{array}{c}\text { Neutral } \\
3\end{array}$ & 4 & $\begin{array}{c}\text { Very } \\
\text { Helpful } \\
5\end{array}$ \\
\hline Spending less time marketing the market. & $\square$ & $\square$ & $\square$ & $\square$ & $\square$ \\
\hline $\begin{array}{l}\text { Increasing my return on investment (e.g. financial } \\
\text { or non-financial). }\end{array}$ & $\square$ & $\square$ & $\square$ & $\square$ & $\square$ \\
\hline $\begin{array}{l}\text { Having more time to develop new programs or } \\
\text { business ventures for the market }\end{array}$ & $\square$ & $\square$ & $\square$ & $\square$ & $\square$ \\
\hline $\begin{array}{l}\text { Strengthening my relationships with other food } \\
\text { system players/sectors. }\end{array}$ & $\square$ & $\square$ & $\square$ & $\square$ & $\square$ \\
\hline $\begin{array}{l}\text { Increased access to other food system } \\
\text { players/sectors (e.g. consumers, distributors) }\end{array}$ & $\square$ & $\square$ & $\square$ & $\square$ & $\square$ \\
\hline $\begin{array}{l}\text { Having a better reputation within our local food } \\
\text { community. }\end{array}$ & $\square$ & $\square$ & $\square$ & $\square$ & $\square$ \\
\hline $\begin{array}{l}\text { Increasing my knowledge of local food systems so I } \\
\text { can better educate vendors and customers. }\end{array}$ & $\square$ & $\square$ & $\square$ & $\square$ & $\square$ \\
\hline Helping me be more effective in my field of work. & $\square$ & $\square$ & $\square$ & $\square$ & $\square$ \\
\hline
\end{tabular}

\begin{tabular}{|c|c|c|c|c|c|}
\hline & $\begin{array}{l}\text { Not at all } \\
\quad 1\end{array}$ & 2 & $\begin{array}{c}\text { Neutral } \\
3\end{array}$ & 4 & $\begin{array}{l}\text { Very much } \\
5\end{array}$ \\
\hline $\begin{array}{l}\text { Opening your farmers' market venue for others use } \\
\text { (i.e. CSA pick-up for farmers). }\end{array}$ & $\square$ & $\square$ & $\square$ & $\square$ & $\square$ \\
\hline $\begin{array}{l}\text { Helping farmers combine product to sell to large, } \\
\text { local institutional buyers. }\end{array}$ & $\square$ & $\square$ & $\square$ & $\square$ & $\square$ \\
\hline $\begin{array}{l}\text { Financially contribute to an event that promotes } \\
\text { the market or other partners. }\end{array}$ & $\square$ & $\square$ & $\square$ & $\square$ & $\square$ \\
\hline $\begin{array}{l}\text { Volunteer your time or other non-financial } \\
\text { resources for joint local marketing efforts. }\end{array}$ & $\square$ & $\square$ & $\square$ & $\square$ & $\square$ \\
\hline $\begin{array}{l}\text { Jointly fund marketing that promotes your } \\
\text { local/regional food system. }\end{array}$ & $\square$ & $\square$ & $\square$ & $\square$ & $\square$ \\
\hline $\begin{array}{l}\text { Contribute support (financial or non-financial) to } \\
\text { build local food distribution infrastructure. }\end{array}$ & $\square$ & $\square$ & $\square$ & $\square$ & $\square$ \\
\hline $\begin{array}{l}\text { Contribute support (financial or non-financial) to } \\
\text { advocate for policy change that supports a } \\
\text { sustainable local/regional food system. }\end{array}$ & $\square$ & $\square$ & $\square$ & $\square$ & $\square$ \\
\hline
\end{tabular}

7) Considering the benefits, costs, and risks to collaboration, are there ways you prefer to interact with other food system players? Check all that apply.

I avoid other food system player's requests to collaborate.

I agree to collaborate, but don't really participate.

I prefer to be a leader instead of working collaboratively.

I prefer to focus more on being a competitive food system player, rather than a collaborator.

Other (please specify): 


\section{8) If you do not collaborate, please select all the reasons why. Check all that apply.}

I don't have the time.

My costs to collaborate outweigh the benefits.

I am not sure of the possible benefits.

Other collaborators would benefit more than the market would.

The market doesn't benefit enough from partnering/collaborating with others.

Depending on others is too risky.

Other (please specify):

9) Please rate how interested you are in local food movements.

\begin{tabular}{|c|c|c|c|c|c|}
\hline & $\begin{array}{c}\text { Not at all } \\
\text { Interested } \\
1\end{array}$ & 2 & $\begin{array}{c}\text { Neutral } \\
3\end{array}$ & 4 & $\begin{array}{c}\text { Very } \\
\text { Interested } \\
5\end{array}$ \\
\hline Level of interest & $\square$ & $\square$ & $\square$ & $\square$ & $\square$ \\
\hline
\end{tabular}

10) How important do you think collaboration is to local food movements?

\begin{tabular}{lccccc}
\hline & Not at all & Neutral & Very & Important \\
Important & 1 & 2 & 3 & 4 & 5 \\
Collaboration & $\square$ & $\square$ & $\square$ & $\square$ & $\square$
\end{tabular}

11) Thinking about all the ways to collaborate, to what extent do you agree or disagree with the following statement.

\begin{tabular}{|c|c|c|c|c|c|}
\hline & $\begin{array}{l}\text { Strongly } \\
\text { Disagree } \\
1\end{array}$ & 2 & $\begin{array}{c}\text { Neutral } \\
3\end{array}$ & 4 & $\begin{array}{l}\text { Strongly } \\
\text { Agree } \\
5\end{array}$ \\
\hline $\begin{array}{l}\text { The more effort I give to collaborating, the } \\
\text { more benefits I will receive. }\end{array}$ & $\square$ & $\square$ & $\square$ & $\square$ & $\square$ \\
\hline
\end{tabular}


12) Farmers' markets play many roles; please indicate the extent to which you agree or disagree with the following:

\begin{tabular}{|c|c|c|c|c|c|}
\hline Farmers' markets should... & $\begin{array}{l}\text { Strongly } \\
\text { Disagree } \\
1\end{array}$ & 2 & $\begin{array}{c}\text { Neutral } \\
3\end{array}$ & 4 & $\begin{array}{l}\text { Strongly } \\
\text { Agree } \\
5\end{array}$ \\
\hline $\begin{array}{l}\text {...ensure customers have freedom to explore the } \\
\text { market without purchasing anything. }\end{array}$ & $\square$ & $\square$ & $\square$ & $\square$ & $\square$ \\
\hline $\begin{array}{l}\text {...work to make the farmers market a place where } \\
\text { people can socialize. }\end{array}$ & $\square$ & $\square$ & $\square$ & $\square$ & $\square$ \\
\hline $\begin{array}{l}\text {...help educate customers about the local food } \\
\text { system. }\end{array}$ & $\square$ & $\square$ & $\square$ & $\square$ & $\square$ \\
\hline $\begin{array}{l}\text {...make sure the farmers market is an enjoyable } \\
\text { experience for customers. }\end{array}$ & $\square$ & $\square$ & $\square$ & $\square$ & $\square$ \\
\hline ...provide an attractive market space. & $\square$ & $\square$ & $\square$ & $\square$ & $\square$ \\
\hline $\begin{array}{l}\text {...provide customers with added services/experiences } \\
\text { (e.g. cooking demonstrations, free samples, and } \\
\text { information). }\end{array}$ & $\square$ & $\square$ & $\square$ & $\square$ & $\square$ \\
\hline
\end{tabular}

13) To what extent do you agree or disagree with the following statement?

\begin{tabular}{|c|c|c|c|c|c|}
\hline & $\begin{array}{l}\text { Strongly } \\
\text { Disagree } \\
1\end{array}$ & 2 & $\begin{array}{c}\text { Neutral } \\
3\end{array}$ & 4 & $\begin{array}{l}\text { Strongly } \\
\text { Agree } \\
5\end{array}$ \\
\hline $\begin{array}{l}\text { I help provide a leisure experience at the } \\
\text { farmers' market }\end{array}$ & $\square$ & $\square$ & $\square$ & $\square$ & $\square$ \\
\hline
\end{tabular}

14) We all have our own ideas about what leisure is. Thinking about a farmers' market, please indicate how strongly you agree or disagree with the following statement.

\begin{tabular}{|c|c|c|c|c|c|}
\hline & $\begin{array}{l}\text { Strongly } \\
\text { Disagree } \\
1\end{array}$ & 2 & $\begin{array}{c}\text { Neutral } \\
3\end{array}$ & 4 & $\begin{array}{l}\text { Strongly } \\
\text { Agree } \\
5\end{array}$ \\
\hline $\begin{array}{l}\text { Farmers' markets provide a leisure } \\
\text { experience. }\end{array}$ & $\square$ & $\square$ & $\square$ & $\square$ & $\square$ \\
\hline
\end{tabular}

15) Managing the farmers' market is...

$\square \quad$...my full-time occupation.

$\square \quad$...a part-time occupation.

...volunteer work. 


\section{6) To what extent do you agree or disagree with the following statements?}

\begin{tabular}{|c|c|c|c|c|c|}
\hline People go to farmers markets to... & $\begin{array}{c}\text { Strongly } \\
\text { Disagree } \\
1\end{array}$ & 2 & $\begin{array}{c}\text { Neutral } \\
3\end{array}$ & 4 & $\begin{array}{c}\text { Strongly } \\
\text { Agree } \\
5\end{array}$ \\
\hline ...relax physically. & $\square$ & $\square$ & $\square$ & $\square$ & $\square$ \\
\hline ...feel free to choose what they want to do or buy. & $\square$ & $\square$ & $\square$ & $\square$ & $\square$ \\
\hline ...tell others about the market. & $\square$ & $\square$ & $\square$ & $\square$ & $\square$ \\
\hline ...have others think highly of them for going. & $\square$ & $\square$ & $\square$ & $\square$ & $\square$ \\
\hline ...do something with their family. & $\square$ & $\square$ & $\square$ & $\square$ & $\square$ \\
\hline ...have a pleasurable experience. & $\square$ & $\square$ & $\square$ & $\square$ & $\square$ \\
\hline ...be with people who have similar values. & $\square$ & $\square$ & $\square$ & $\square$ & $\square$ \\
\hline ...meet other people. & $\square$ & $\square$ & $\square$ & $\square$ & $\square$ \\
\hline ...get away from the usual demands of life. & $\square$ & $\square$ & $\square$ & $\square$ & $\square$ \\
\hline ...learn about things while there. & $\square$ & $\square$ & $\square$ & $\square$ & $\square$ \\
\hline ...obtain fresh produce. & $\square$ & $\square$ & $\square$ & $\square$ & $\square$ \\
\hline ...access locally produced food. & $\square$ & $\square$ & $\square$ & $\square$ & $\square$ \\
\hline ...support local agriculture. & $\square$ & $\square$ & $\square$ & $\square$ & $\square$ \\
\hline ...just buy groceries. & $\square$ & $\square$ & $\square$ & $\square$ & $\square$ \\
\hline ...support their local economy. & $\square$ & $\square$ & $\square$ & $\square$ & $\square$ \\
\hline ...to get what they need. & $\square$ & $\square$ & $\square$ & $\square$ & $\square$ \\
\hline Other (please specify): & $\square$ & $\square$ & $\square$ & $\square$ & $\square$ \\
\hline
\end{tabular}

17) How many vendors does the farmers' market you manage host?

18) How many years have you been a farmers' market manager?

19) How long has your farmers' market been in operation?

20) What is your five digit zip code for your farming location? 
21) What year were you born?

24) What is your gender?

22) What is the highest level of formal education you have completed?

$\square \quad$ Less than 12 years

$\square \quad$ High school graduate/GED

$\square \quad$ Some college

College degree

Thank You for completing the survey. Your time and input is greatly appreciated!

Please return the survey in the envelope provided to:

\author{
Farmers' Market Study \\ Attn: Crystal Miller \\ 480 Wilson Road, Room 131 \\ East Lansing, MI 48824-1222
}

